\title{
Comparative Analysis of Maintenance Models in Forest Machines
}

\author{
Carlos Cézar Cavassin Diniz ${ }^{1}$ (1) 0000-0002-1578-4392 \\ Eduardo Silva Lopes ${ }^{2}$ (1) 0000-0001-7008-8667 \\ Henrique Soares Koehler ${ }^{1}$ (D) 0000-0001-7727-7049 \\ Gabriel Magalhães Miranda ${ }^{2}$ (1) 0000-0001-8536-6658 \\ José Paccola ${ }^{3}$ (1) 0000-0002-0325-7683
}

\begin{abstract}
This study aimed to perform a comparative analysis between models of mechanical maintenance in forestry machines, subsidizing operational planning in order to reduce production costs. The work was conducted in a forestry company with feller bunchers, skidders and harvester machines. The comparative analysis included the Traditional Maintenance and the World Class Maintenance (WCM) models in the judgment of mechanical availability, hydraulic oil consumption and maintenance costs. Using the WCM maintenance model, the results showed a $5 \%$ increase in mechanical availability and a $60 \%$ reduction in hydraulic oil consumption. The maintenance cost increased by $3 \%$ in the WCM model due to an investment in infrastructure and the training of mechanics, but with the potential for better maintenance of forest machines, along with improvements in operational safety, production capacity and longer machine life.
\end{abstract}

Keywords: forestry machinery, mechanical availability, planning.

\section{INTRODUCTION AND OBJECTIVES}

Most Brazilian forestry companies are using modern and high technology machines in performing wood harvesting operations, which consist in high complexity and high costs compared to other forest operations and which need improvement in mechanical maintenance procedures (Bramucci \& Seixas, 2002; Fiedler et al., 2008; Leite et al., 2014; Rocha et al., 2009; Spinelli et al., 2009). This situation requires constant improvements in work techniques, greater operational efficiency and new management maintenance models, guaranteeing the machines' maintenance and the reduction of production costs.

The mechanical maintenance of wood harvesting machines is of great importance within the forest production process, as it is able to represent from 50 to $60 \%$ of the machine's total operational costs (Lopes et al., 2014; Silva et al., 2010). Therefore, it is necessary to increase the machines' mechanical availability and the reliability of the operations, since these factors are fundamental to increase the yield and to reduce costs in the production processes (Dario et al., 2014).

Muchiri et al. (2011) and Mishra et al. (2015) infer that maintenance can be defined as the combination of all administrative and technical activities aimed at maintaining machines, facilities and other physical assets under operational conditions. Paccola (2017) considers maintenance as a set of actions that are necessary for an item to be conserved or restored for it to remain in accordance with a pre-established condition.

Regarding maintenance, some factors such as history of failures, parts in stock, mechanics and operators' training, and maintenance methodologies (among others) need to be considered to assure the maximum machines' productive capacity with low costs and an optimum return of investments guarantee. Kardec et al. (2002) and Pacolla (2017) commented that the mechanical machine's availability is directly dependent on the performance of the preventive maintenance, which is fundamental in the production process. Therefore, interventions

\footnotetext{
${ }^{1}$ Universidade Federal do Paraná (UFPR), Curitiba, PR, Brasil

${ }^{2}$ Universidade Estadual do Centro-Oeste (UNICENTRO), Irati, PR, Brasil

${ }^{3}$ Consultor, Telêmaco Borba, PR, Brasil
} 
are necessary to avoid correcting machine defects during the shift work.

Among the main programs, World Class Maintenance (WCM) stands out as a basis for preventive maintenance. Yamashina (2000) comments that WCM aims to achieve world-class maintenance through processing leadership and involving best practices from other maintenance programs such as Total Productive Maintenance (TPM). In this sense, WCM promotes a culture change regarding reactive maintenance methods hitherto employed by many industry segments (Mishra et al., 2006; Mishra et al., 2015; Yamashina, 2000).

Analyzing the productivity of machines in a whole tree system, Fiedler et al. (2008) stated that the high corrective maintenance number results in low mechanical availability, with direct interference in planning and in production capacity of the wood harvesting operations. Simões et al. (2014) points out that the adequately mechanical maintenance performance translates into a high mechanical availability index, which was also confirmed by Lopes \& Diniz (2015) by studying forest extraction activity.

The objective of this study was to perform a comparative analysis between two models of mechanical maintenance in wood harvesting machines, aiming to identify the best procedure to be adopted by the forest company and to subsidize operations planning and to reduce production costs.

\section{MATERIALS AND METHODS}

This study was carried out in a forest company located in the municipality of Telêmaco Borba, in the region of Campos Gerais, Paraná, between the geographical coordinates $24^{\circ} 19^{\prime} 26^{\prime \prime}$ and $50^{\circ} 36^{\prime} 57^{\prime \prime}$, and an average altitude of $750 \mathrm{~m}$. The climate of the region is defined as a transition between $\mathrm{Cfa}$ and $\mathrm{Cfb}$, subtropical humid, with a varying average temperature from $16.3^{\circ} \mathrm{C}$ to $23.2^{\circ} \mathrm{C}$ and average annual rainfall between 1,478 to $1,700 \mathrm{~mm}$ (Barbosa et al., 2007).

The data were obtained in the operational areas during Eucalyptus grandis and Pinus taeda wood harvesting stands, with cutting ages of seven and 17 years, respectively, and an average individual tree volume in both species ranging from 0.36 to $0.42 \mathrm{~m}^{3} /$ tree.

The company's wood harvesting system was full tree, composed of two feller bunchers (FB) that carried out the felled trees and stacked them inside the plot, two skidders (SK) that dragged the trees to the edge of the plots, and two harvesters (HV) responsible for processing trees into logs of different dimensions, as shown in Table 1 . The machines worked in two nine-hour daily shifts, every day of the week, minus the necessary mealtime, totaling 540 hours available for the operation.

Table 1. Characteristics of the evaluated wood harvesting machines.

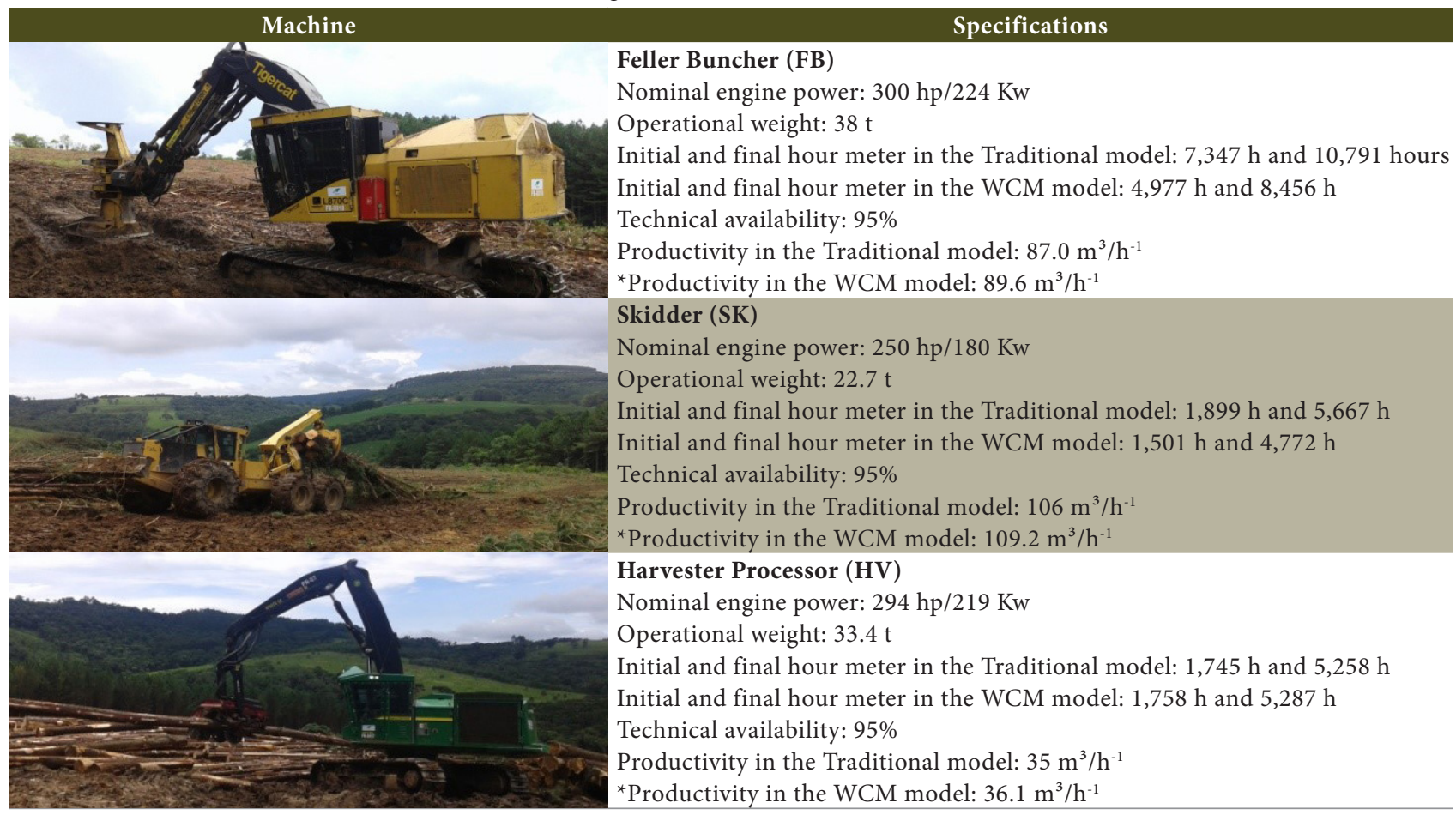

${ }^{\star}$ Productivity in the Traditional model presented a reduction of 3\% in relation to WCM during the study due to the entrance of particulates in the hydraulic system. 
The existing infrastructure in the mechanical maintenance models is presented in Figure 1.The items numbered from one to eight belonged to the Traditional model, while the items from three to 12 were from the WCM model.

The traditional maintenance model activities were only based on the performance of corrective and preventive lubrication maintenance, based on the manufacturer's recommendations. In contrast, weekly preventive maintenance was used in the WCM model, with verification of various machine items, strategic reviews and fault analysis, as well as corrective maintenance, when necessary.

The comparison between the traditional and the WCM maintenance models was performed by obtaining the machines' mechanical availability, hydraulic oil consumption and maintenance costs, obtained during the daily wood harvesting operations in both stands from 2014 to 2016 for 12 months. In 2014, the adopted maintenance model in the company was the Traditional one, while from 2015 onwards the WCM model was used.

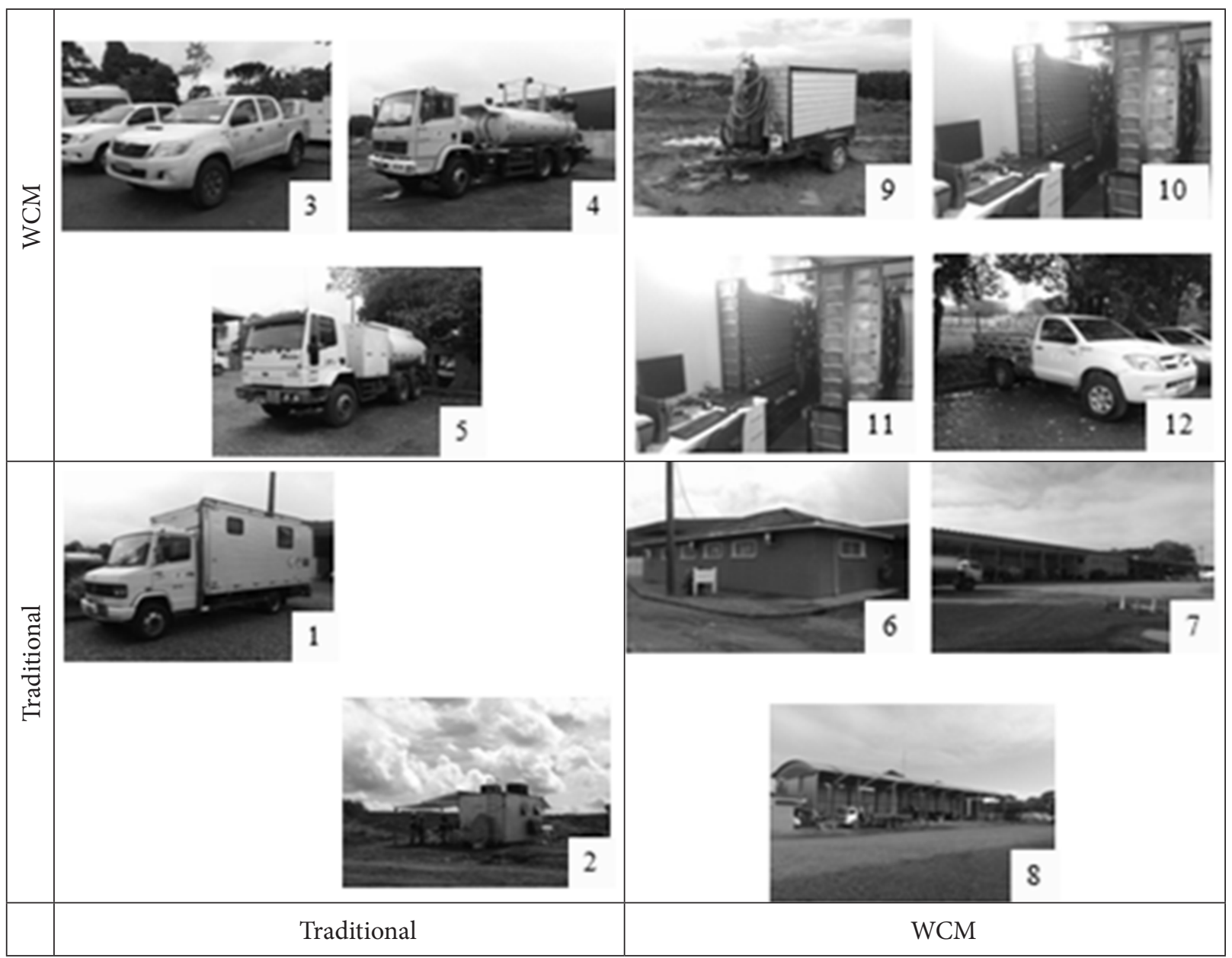

Figure 1. Characteristics of the traditional and WCM maintenance models.

1: truck workshop; 2: living area; 3: support car; 4: water truck; 5: supply truck; 6: central warehouse; 7 and 8: central workshop; 9: welding trolley; 10: field office; 11: field warehouse; 12: milk run.

The mechanical availability was obtained by Equation 1 , adapted from Rocha et al. (2009), Simões \& Fenner (2010), Santos et al. (2013) and Guedes et al. (2017). It is defined as the percentage of the scheduled service time in which the machines were available to perform a given activity, disregarding the maintenance time.

$$
\mathrm{DM}=\frac{\mathrm{HW}-\mathrm{MH}}{\mathrm{HW}}, 100
$$

DM: degree of mechanical availability (\%); HW: scheduled work hours; MH: maintenance hours. 
The average hydraulic oil consumption was calculated by the ratio between the amount of hydraulic oil consumed by the machines regarding the total number of hours worked, obtained by Equation 2:

$$
\mathrm{CHO}=\frac{\mathrm{LHO}}{\mathrm{HW}}
$$

CHO: average consumption of hydraulic oil (liters/hour); LHO: quantity of consumed hydraulic oil in the month (liters); HW: quantity of worked hours in the month.

Maintenance expenses on both models considered the following costs: personnel, materials, external services and support.

The personnel cost included the expenses on salaries, social charges and benefits provided by the company (profit sharing, training of the maintenance team), obtained by Equation 3:

$$
\mathrm{PC}=\frac{\mathrm{SL}+\mathrm{CH}+\mathrm{BN}+\mathrm{TR}}{\mathrm{HW}}
$$

PC: personnel costs (R\$/hour); SL: salaries (R\$); $\mathrm{CH}$ : charges (R\$); BN: benefits (R\$); TR: training and recycling (R\$); HW: quantity of worked hours in the month.

The materials' cost was related to spare parts, water consumption, fixed assets, warehouse management and the purchasing sector, as shown in Equation 4:

$$
\mathrm{MTC}=\frac{\mathrm{MT}}{\mathrm{HW}}
$$

MTC: materials cost (R\$/hour); MT: materials (R\$); HW: quantity of worked hours in the month.

The external cost refers to the monthly values of contracts with outsourced companies that perform some services, such as washing machines, welding, oil analysis, etc. (Equation 5):

$$
\mathrm{ESC}=\frac{\mathrm{OC}}{\mathrm{HW}}
$$

ESC: external services cost (R $\$ /$ hour); OC: outsourced contracts (R\$); HW: quantity of worked hours in the month.

The cost of the support referred to the maintenance infrastructure, such as: support vehicles, supply truck, welding cart, warehouse, etc., as shown in Equation 6:

$$
\mathrm{SC}=\frac{\mathrm{CI}}{\mathrm{HW}}
$$

SC: support cost (R \$/hour); CI: cost of inputs; HW: quantity of worked hours in the month.

The total maintenance cost was obtained by the sum of the costs of personnel, materials, services and support, calculated by Equation 7 :

$$
\mathrm{MC}=\mathrm{PC}+\mathrm{CMT}+\mathrm{SEC}+\mathrm{SC}
$$

MC: maintenance cost (R $\$ /$ hour); PC: personnel cost (R\$/he); MTC: materials cost (R $\$ /$ hour); SEC: services cost (R\$/hour); SC: support cost (R\$/hour).

A completely randomized design with factorial arrangement was used in this study, in which six treatments with 12 replicates were tested. The treatments were represented by the combination of three machines (feller buncher, skidder and harvester) and two maintenance models (Traditional and WCM). The results were submitted to the variance analysis technique, and in the cases in which there were significant differences, the Tukey test ( $p$-value $<0.05$ ) was performed through the Assistat 7.7 beta program.

\section{RESULTS}

The results of the mechanical availability of the studied machines are presented in Figure 2. It is possible to notice an increase in the machines' mechanical availability indexes when submitted to the WCM maintenance, with a significant difference between the maintenance models detected by the Tukey test $(p$-value $<0.05)$ regarding the feller, buncher and skidder. This result is highlighted in the skidder, which presented a $7.5 \%$ increase in mechanical availability with the implementation of the WCM maintenance model.

The WCM maintenance model showed greater efficiency compared to the traditional model as shown in Figure 3, providing a mean reduction in the hydraulic oil consumption of $60 \%$, resulting in saving of 120 liters of hydraulic oil per month for each studied machine.

It is important to note that the largest reduction in hydraulic oil consumption occurred in the skidder, with an average of $78 \%$, followed by the harvester and feller buncher with $54 \%$ and $48 \%$, respectively. The results showed that between the maintenance models a significant difference in the hydraulic oil consumption was detected by the Tukey test $(p$-value $<0.05)$. 


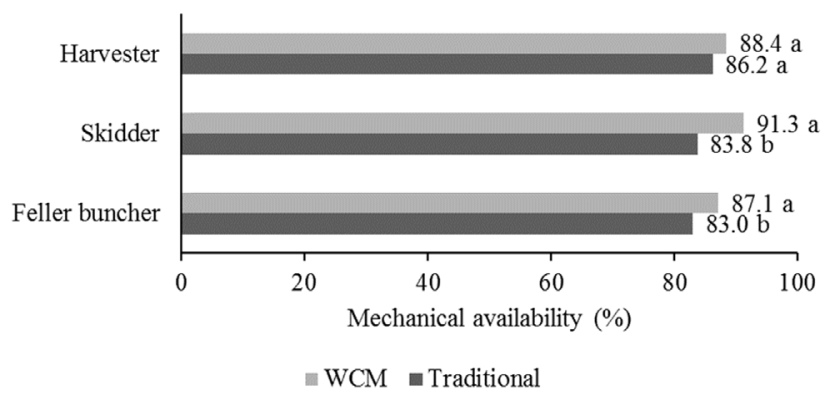

Figure 2. Mechanical availability of wood harvesting machines subject to the traditional and WCM mechanical maintenance models.

Means followed by the same letter do not differ statistically by the Tukey test at $5 \%$ probability.

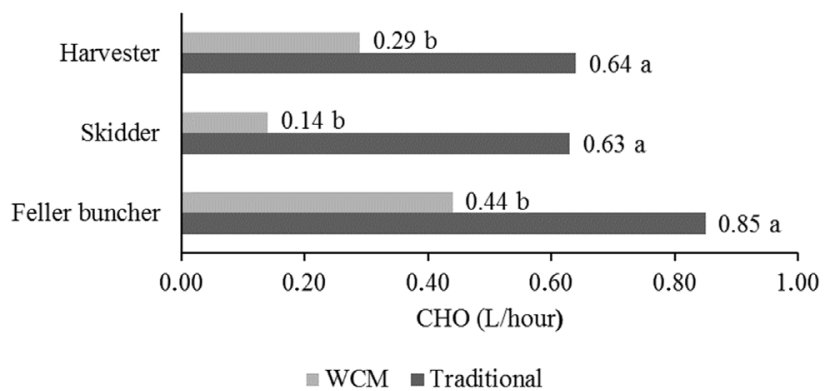

Figure 3. Average hydraulic oil consumption $(\mathrm{CHO})$ of the wood harvesting machines submitted to the traditional and the WCM mechanical maintenance models.

Means followed by the same letter do not differ statistically by the Tukey test at $5 \%$ probability.

Regarding the maintenance cost, it was possible to notice a 3\% increase in the WCM model, exhibited in Figure 4, caused by the investments in hiring skilled labor, training mechanics and improving the field infrastructure; however, without these investments, there was a significant difference, detected by the Tukey test ( $p$-value $<0.05)$, between the mechanical maintenance models and the studied machines.

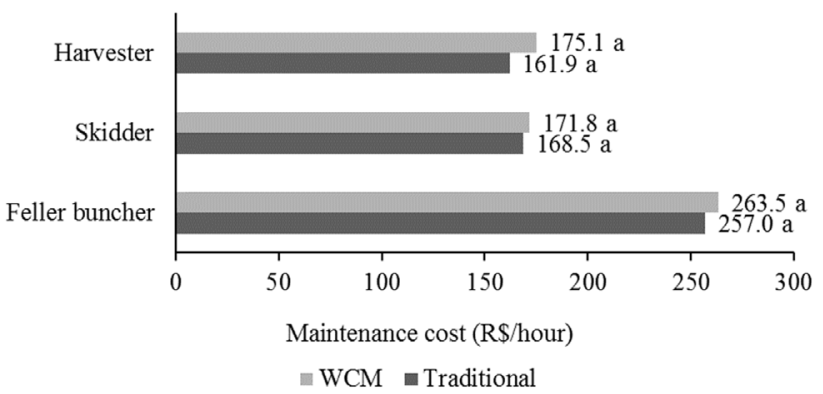

Figure 4. Maintenance costs per worked hour of the wood harvesting machines submitted to the traditional and the WCM mechanical maintenance models.

Means followed by the same letter do not differ statistically by the Tukey test at $5 \%$ probability.

The Table 2 presents the results of the production cost for each evaluated maintenance model. As observed, the utilization degree product of the technical and mechanical availability-of each machine was obtained, as previously calculated. Considering the utilization degree obtained from the 540 available work hours, it was possible to obtain an estimate of how much each machine operated in the study months.

With the worked hours increase regarding the Traditional model, the WCM model gained $8.7 \%$ considering the monthly production estimate of all the machines. According to Silva et al. (2010) and Lopes et al. (2014), the maintenance cost represents around $60 \%$ of the wood harvesting machine operating cost. Therefore, the operating cost for the machines per worked hour was obtained, and consequently, each machine's production cost in maintenance models.

As observed, the harvester presented an increase in the production cost of the WCM maintenance model. However, the feller buncher and the skidder machines presented reduced production cost, showing the viability of the WCM maintenance model.

Table 2. Production costs of the wood harvesting machines submitted to the traditional and the WCM mechanical maintenance models.

\begin{tabular}{|c|c|c|c|c|c|c|c|c|}
\hline Model & MC & UD (\%) & HT (month) & $\operatorname{PR}\left(\mathrm{m}^{3} / \mathrm{h}^{-1}\right)$ & PD $\left(\mathrm{m}^{3} /\right.$ month $)$ & $\mathrm{CO}\left(\mathbf{R} \$ / \mathbf{h}^{-1}\right)$ & OC (R\$/month) & $\mathrm{PC}\left(\mathbf{R} \$ / \mathbf{m}^{3}\right)$ \\
\hline \multirow{3}{*}{ Traditional } & FB & 78.9 & 425.79 & 87.00 & $37,043.73$ & 428.33 & $182,380.05$ & 4.92 \\
\hline & SK & 79.6 & 429.89 & 106.00 & $45,568.76$ & 280.83 & $120,728.57$ & 2.65 \\
\hline & $\mathrm{HV}$ & 81.9 & 442.21 & 35.00 & $15,477.21$ & 269.83 & $119,321.92$ & 7.71 \\
\hline \multirow{3}{*}{ WCM } & FB & 82.7 & 446.82 & 89.61 & $40,039.81$ & 439.17 & $196,229.77$ & 4.90 \\
\hline & SK & 86.7 & 468.37 & 109.18 & $51,136.53$ & 286.33 & $134,109.66$ & 2.62 \\
\hline & $\mathrm{HV}$ & 84.0 & 453.49 & 36.05 & $16,348.39$ & 291.83 & $132,344.08$ & 8.10 \\
\hline
\end{tabular}

MC: machine; UD: utilization degree; HW: worked hours; PR: productivity; PD: production; OC: operational costs; PC: production cost. 


\section{DISCUSSION}

From the obtained results, it was evident that the WCM model provided an increase in the mechanical availability of the studied machines, except for the harvester which did not present significant difference between the maintenance models. This result can be attributed to the little variation in this machine's activity, which worked in a constant rotation and without being excessively forced. Another aspect that contributed to the increase in the mechanical availability of the machines in the WCM was the mechanics' training and the investment made to improve the field infrastructure, providing greater agility and efficiency in servicing the machines.

The mechanical availability of the feller buncher was below the values obtained by Simões et al. (2014) and Pereira et al. (2015) who gathered values greater than $90 \%$. However, such results were obtained in studies conducted in a short period of time, whereas the data were collected throughout one year, obtaining more reliable results.

Regarding the hydraulic oil consumption, it was possible to perceive greater efficiency in the WCM model than in the Traditional model. This result is directly related to the new preventive maintenance activities carried out in this model, such as checks of loose terminals and worn hoses, so that rupture occurrence and hydraulic oil leakage can be predicted.

The feller buncher was the machine that presented the highest hydraulic oil consumption, as justified by the greater number of commands used in the tree felling operation. In addition, another aspect that caused greater consumption referred to the arrangement of hydraulic systems, which were mostly unprotected, in addition to higher rated power in the engine. These situations were also observed in the harvester.

The machine that presented the lowest maintenance cost was the skidder, while the feller buncher showed the highest cost. These results were similar to those obtained by Rocha et al. (2009) in his study of the productivity and machines cost in the whole tree harvesting system. The lower maintenance cost of the skidder can be explained by the machine's characteristics which has a closed hydraulic system, with greater protection of the hoses and greater robustness. Lopes et al. (2017) also points out that this machine consumes longer operational cycle time in displacement, reducing exposure to trunks and branches, unlike what normally occurs with the feller buncher and harvester.

The harvester presented an increase in the production cost during the WCM model, since the feller buncher and skidder machines presented reduced cost, showing the feasibility of the model. This result was possible mainly because of the increase in the machines' mechanical availability in the WCM model, allowing an increase in the number of hours worked, thus increasing the monthly production of each machine.

Another factor that led to this result was the slight decrease in the machines' productivity while using the Traditional model. The explanation for this behavior is linked to the machine's hydraulic system. Because of impurities, such as dust, the oil became more viscous, making it difficult for the machine to perform its movements, and because they present slower movements, their productivity decreases.

It is important to point out that it is almost impossible to verify this fact, requiring months of information gathering to arrive at such a conclusion. In this way, by applying a greater preventive maintenance amount of practices it was verified that the WCM maintenance model offered greater reliability of the machines in performing the forest operations, with reduced failures and greater operational safety.

Although the maintenance cost in the WCM model presented an average increase of $3 \%$ in relation to the Traditional one, it showed potential for adoption in the wood harvesting machines mechanical maintenance because of a tendency to reduce costs with improvement in the techniques and operational procedures.

\section{CONCLUSIONS}

The WCM model provided an increase in the mechanical availability of wood harvesting machines in relation to the Traditional model.

The improvement in the preventive maintenance techniques applied in the WCM model, with greater intervention in the components causing wear contributed to reducing the hydraulic oil consumption of the machines.

The initial investments in infrastructure and in training the teams for implementing the WCM model contributed to an increase in the maintenance cost when compared to the Traditional model but could be amortized over time with the maturing of the process in the future.

\section{ACKNOWLEDGEMENTS}

The authors thank two anonymous reviewers and the Editorin-Chief for their valuable and helpful comments. Special thanks to the Brazilian forest company and to Mr. Eduardo Kremer for their support during data collection.

This study was financed in part by the Coordenação de Aperfeiçoamento de Pessoal de Nível Superior - Brasil (CAPES) - Finance Code 001

\section{SUBMISSION STATUS}

Received: 4 Oct. 2017

Accepted: 3 Aug. 2018 
Associate editor:

Renato Cesar Gonçalves Robert

\section{CORRESPONDENCE TO}

\section{Eduardo Silva Lopes}

Universidade Estadual do Centro-Oeste (UNICENTRO), Rua Professora Maria Roza Zanon de Almeida, Engenheiro Gutierrez, CEP 84505-677. Irati, PR, Brasil

e-mail: eslopes@unicentro.br

\section{REFERENCES}

Barbosa CEA, Benato T, Cavalheiro AL, Torezan JMD. Diversity of regenerating plants in reforestations with Araucaria angustifolia (Bertol.) O. Kuntze of 12, 22, 35, and 43 years of age in Parana State, Brazil. Restoration Ecology 2007; 17(1): 60-67. 10.1111/j.1526-100X.2007.00335.x

Bramucci M, Seixas F. Determinação e quantificação de fatores de influência sobre a produtividade de "harvesters" na colheita florestal. Scientia Forestalis 2002; 62: 62-74.

Dario M, Silva EM, Netto MS, Pires SRI. Indicadores de desempenho, práticas e custos da manutenção na gestão de pneus de uma empresa de transportes. Revista Produção Online 2014; 14(4): 1235-1269. 10.14488/1676-1901.v14i4.1450

Fernandes HC, Burla ER, Leite ES, Minette LJ. Avaliação técnica e econômica de um "harvester" em diferentes condições de terreno e produtividade da floresta. Scientia Forestalis 2013; 41(97): 145-151.

Fiedler NC, Rocha EB, Lopes ES. Análise da produtividade de um sistema de colheita de árvores inteiras no norte do estado de Goiás. Floresta 2008; 38(4): 577-586. 10.5380/rf.v38i4.13153

Guedes IL, Amaral EJ, Leite ES, Fernandes HC, Sant'Anna CM. Avaliação do desempenho e custos de dois sistemas de cabos aéreos na extração de madeira de eucalipto. Ciência Florestal 2017; 27(2): 571-580. 10.5902/1980509827737

Kardec A, Nascif J, Baroni T. Gestão estratégica e técnicas preditivas. Rio de Janeiro: Qualitymark; 2002.

Leite ES, Fernandes HC, Minette LJ, Souza AP, Leite HG, Guedes IL. Modelagem do desempenho da extração de madeira pelo "forwarder". Revista Árvore 2014; 38(5): 879-887. 10.1590/S0100-67622014000500012

Lopes ES, Diniz CC. Produtividade do trator florestal chocker skidder na extração de madeira em terrenos declivosos. Floresta 2015; 45(3): 625-634. 10.5380/rf.v45i3.36409

Lopes ES, Oliveira D, Rodrigues CK, Drinko CH. Variables influencing working time and skidder productivity in wood extraction. Nativa 2017; 5(4): 298-302. 10.5935/2318-7670.v05n04a12
Lopes ES, Oliveira D, Sampietro JA. Influence of wheeled types of a skidder on productivity and cost of the forest harvesting. Floresta 2014; 44(1): 53-62. 10.5380/rf.v44i1.31356

Mishra RP, Anand G, Kodali RB. Development of a framework for world-class maintenance systems. Journal of Advanced Manufacturing Systems 2006; 5(2): 141-165. 10.1142/S0219686706000807

Mishra RP, Kodali RB, Gupta G, Mundra N. Development of a framework for implementation of world-class maintenance systems using interpretive structural modeling approach. Procedia CIRP 2015; 26: 424-429. 10.1016/j.procir.2014.07.174

Muchiri P, Pintelon L, Gelders L, Martin H. Development of maintenance function performance measurement framework and indicators. International Journal of Production Economics 2011; 131(1): 295-302. 10.1016/j.ijpe.2010.04.039

Paccola JE. Manutenção e operação de equipamentos móveis. 2nd ed. São José dos Campos: JAC; 2017.

Pereira ALN, Lopes ES, Dias AN. Análise técnica e de custo do feller buncher e skidder na colheita de madeira em diferentes produtividades do povoamento. Ciência Florestal 2015; 25(4): 981-989. 10.5902/1980509820659

Rocha EB, Fiedler NC, Alves RT, Lopes ES, Guimarães PP, Peroni L. Produtividade e custos de um sistema de colheita de árvores inteiras. Cerne 2009; 15(3): 372-381.

Santos PHA, Souza AP, Marzano FLC, Minette LJ. Produtividade e custos de extração de madeira de eucalipto com Clambunk Skidder. Revista Árvore 2013; 37(3): 511-518. 10.1590/S0100-67622013000300014

Silva EN, Machado CC, Minette LJ, Souza AP, Fernandes HC, Silva ML et al. Avaliação técnica e econômica do corte mecanizado de Pinus sp. com harvester. Revista Árvore 2010; 34(4): 745-753. 10.1590/S0100-67622010000400019

Simões D, Fenner PT. Avaliação técnica e econômica do forwarder na extração de madeira em povoamento de eucalipto de primeiro corte. Floresta 2010; 40(4): 711-720. 10.5380/rf.v40i4.20323

Simões D, Fenner PT, Esperancini MST. Avaliação técnica e econômica da colheita de florestas de eucalipto com harvester. Scientia Forestalis 2010; 38(88): 611-618.

Simões D, Fenner PT, Esperancini MST. Produtividade e custos do feller-buncher e processador florestal em povoamento de eucalipto de primeiro corte. Ciência Florestal 2014; 20(3): 621-630. 10.1590/1980-509820142403010.

Spinelli R, Ward SM, Owendec PM. A harvest and transport cost model for Eucalyptus spp. fast-growing short rotation plantations. Biomass and Bioenergy 2009; 33(9): 1265-1270. 10.1016/j.biombioe.2009.05.010

Yamashina, H. Challenge to world-class manufacturing. International Journal of Quality of Reliability Management 2000; 12(34): 30-31. 10.1108/02656710010304546 